\section{Students and Teachers at Private Universities in China}

\section{Jing Lin}

Jing Lin is associate professor in the Department of Educational Policy and Leadership at the University of Maryland. Address: University of Maryland, College of Education, College Park, MD 20742, USA. E-mail: Jinglin@wam.umd.edu.

$\mathrm{P}$ rivate universities in China have been expanding so fast that one wonders if the sky is the limit. Many of the private universities that were founded in the early I990s started with a few dozen students, planning to end up with a few hundred students. However, the deluge of students quickly turned these institutions into campuses with several thousand students. The higher education expansion launched in China since 1998 has ushered in mega universities enrolling 20 to 30 thousand students. Large public teaching universities have been merged to form American-style comprehensive universities, with the intention of creating "world-class" institutions focusing both on research and teaching. Without much time available, private universities have rushed to obtain more land and build more buildings, while doubling and tripling enrollments-to 20 thousand or more than 30 thousand. Within a few short years more than a dozen of them have joined the ranks of mega universities.

\section{Students and Teachers}

The preoccupation during this stage of fast-pace growth has been to build more dormitories, libraries, teaching buildings, and computer labs and to hire teachers to handle the thousands of new students every year. The belief behind the drive is that scale is essential to ensure the survival of private universities, which would otherwise be swallowed up. Now the dust has settled, and for many people, the challenges of improving students' motivation to learn and giving teachers and students autonomy and trust have come to the forefront.

Unlike the public universities, China's private universities were built from scratch. They do not have a well-trained faculty and staff who have worked there for decades and have spent their life shaping the culture and soul of a campus. Instead, the faculty at private universities are hastily assembled - the main segment being retired professors from public universities and the other group, young people fresh from an undergraduate education. While the older faculty work only part time to gain extra income, younger faculty do not have any prior teaching experience. Furthermore, they are hired as "helpers" rather than as "owners of a university." They sign a contract with the university, and their income is determined by the number of teaching hours. Every year, 5 to io percent of faculty are let go, and the rest have to renew their contracts. Tension and anxiety are thus high due to the uncertainty.
Private universities in China are disadvantaged by a government regulation allowing them to admit students only after public universities have done so. Thus they are left with bottom-tier students whose self-esteem has been "battered" many times, especially as a result of the hundreds of tests they have taken during their primary and secondary schooling. The students' low motivation to learn has frustrated teachers and administrators. Seeing them as "problem students," private universities give their students very little autonomy: the students are strictly managed in the dormitory by a "life teacher." A "class director" monitors their thoughts, talks with them, follows them to the running track to do morning exercise, and makes sure that all students are in their dormitories at Io PM every night. Some administrators proudly dub this as a "military style" management. When asked why the students are watched so closely, three reasons are often given: first, parents want the universities to watch over their children so that they study and graduate. Second, the students have poor study habits and lack self-control. Left to themselves many would just hang out with their girlfriends or boyfriends, a phenomenon seen as distracting students from their studies. Third, and most important of all, private universities feel themselves to be very vulnerable. The government regards them with distrust and treats them with suspicion, and society gives them low respect and sees them as the unfortunate choice they are forced to make after their children fail to gain entrance to a public university. Private universities might well be closed down should something go badly wrong. For example, a very shocking murder case occurred in which a student at Yunnan University killed four of his classmates this year. If this had happened at a private university, it would have resulted in a shutdown, whereas a public university can continue on as usual.

\section{Students, however, are resistant to the military- style management. They sneak off campus with- out permission; they upset their teachers with disrespectful attitudes.}

Students, however, are resistant to the military-style management. They sneak off campus without permission; they upset their teachers with disrespectful attitudes. In order to find creative ways to motivate students, universities explore all kinds of methods. One university puts all the blame on the teachers if something happens to the students, making it the teachers' responsibility that students learn and behave appropriately; another university withholds one-third of some faculty members' salaries at the beginning of the month and gives this portion to them only when no complaints are raised by students. Some universities are contemplating channeling student energy in positive directions by setting up all kinds of student clubs and offering elective courses to students through a credit system. 
Obviously, after rapid expansion, private universities need to turn their attention internally to look at what students and teachers need. Surveys indicate that students suspect that private universities promise more than they can offer and that teachers are poised to leave once they find better job opportunities. Teachers experience the tremendous pressure of handling large classes with 50 to 70 students, having to teach about 16 hours a week, and correct hundreds of student assignment books each week. Teachers report that they do not have time to do anything innovative. They also yearn for professional training, which is still a luxury since private universities are preoccupied with minimizing cost. Teachers are constantly looking to jump ship, a major reason being that in many cases they do not have their own housing. With student enrollments increasing by thousands each year, some private universities have asked teachers to move out of campus housing and rent apartments off campus. Universities promise to build housing for young teachers but delay doing so due to the pressure to build more housing for students. "Too many priorities compete for the limited funding we have," the presidents say.

Basically, the factory-style approach to running a university, in response to the rapid expansion, is now being called into question. Students and teachers are demanding to be treated like human beings. They are demanding to study and teach in a setting defined by an autonomous, respectful organizational culture; choices and interdisciplinary learning are needed to motivate them. Professional training is a need that cannot be ignored. Private universities are realizing that the status of having a huge campus and a large number of students is no longer enough to validate the greatness of a university. It is time to slow down and work on the refinement of the interior.

\section{Establishing Endowments for} African Universities-Strategies for Implementation

\section{DamTew Teferra \\ Damtew Teferra is assistant research professor and founding editor-in-chief of the Journal of Higher Education in Africa at the Center for International Higher Education, Campion Hall, Boston College, 02467, USA. E-mail: teferra@bc.edu.}

Not long ago, Brown University, an American Ivy League institution, received \$100 million from a philanthropist as an endowment to build a scholarship fund for needy students. Such philanthropic donations in U.S. higher education are a unique part of the institutional culture in the United States, aided both by tradition and by enabling tax policies. Leading universities enjoy massive endowments, and even many less prestigious colleges and universities have such funds available to assist them. Endowments constitute funds that are invested by the universities; the interest earned is available to spend on academic and other institutional programs.

\section{Endowments Outside the United States}

A few countries, such as Israel, generate massive resources in endowments. Israel generates endowments mainly from the Jewish diaspora community from across the world. Operating under the umbrella of overseas-registered nonprofit organizations such as the American Friends of the Hebrew University, the American Friends of Tel Aviv University, and the Canadian Friends of the Hebrew University-supporters actively generate resources and build endowments for the advancement of higher education in Israel. For instance, American Friends of the Hebrew University raised more than U.S.\$600 million in 2000 and is now gearing up to raise U.S.\$I billion.

Chinese universities also are undertaking similar, though less organized and less robust, initiatives. For instance, the Peking University Education Foundation operates several branches across the world. The North American chapter is committed to strengthening ties between Peking University and all areas of North America and to raising funds to promote cultural, technological, and educational communication and cooperation.

The collaborative initiative between the Nippon and Tokyo Foundations-Japanese philanthropic institutions-may be singled out as the first major endowment initiative involving African higher education institutions.

\section{Endowments in Africa}

Overall, the culture of endowments is not as extensive in other countries as it is in the United States. This is certainly the case in Africa. On the continent, South Africa leads in endowment drives for building scholarly institutions and programs. For example, in 2000, the Development Office of the University of Cape Town (UCT) reported generating Io7 million rand (about U.S.\$Io million) from donors-a I4 percent increase from the previous year. The overseas partners-the UCT Fund (U.S.) and the UCT Trust (U.K.) - were central to achieving this goal, although 60 percent of the campaign funds were raised in South Africa. Through the significant endowment funds that were raised, the university was able to start or continue building endowments for four chairs: the Nelson Mandela Chair of the Humanities, the Lesley Hill Chair of Plant Biology, the Pasvolsky Chair of Conservation Biology, and the Discovery Chair of Exercise and Sports Science.

The collaborative initiative between the Nippon and Tokyo Foundations-Japanese philanthropic institutions-may be singled out as the first major endowment initiative involving African higher education institutions. The foundations committed U.S. \$I million in endowment grants for each of the three African higher education institutions in Egypt, Kenya, 